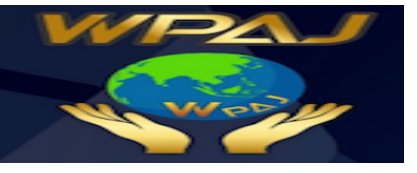

Volume 1 Issue 1, Juni 2019

https://ejournal.unsub.ac.id/index.php/publik

\title{
Implementasi Kebijakan Kawasan Rumah Pangan Lestari (KRPL) Desa Cinta Mekar Kecamatan Serangpanjang
}

\author{
Iwan henri Kusnadi \\ Fakultas Ilmu Administrasi (FIA) Universitas Subang, \\ Iwanhenri01@gmail.com
}

\begin{abstract}
Abstrak
Dalam rangka mewujudkan pemenuhan kebutuhan akan pangan bagi seluruh masyarakat di suatu wilayah,maka ketersediaan pangan menjadi sasaran utama dalam kebijakan pangan bagi pemerintahan suatu negara.Oleh karena itu untuk memperoleh cadangan yang cukup, maka pemerintah membuat satu gerakan untuk meningkatkan keragaman dan kualitas konsumsi pangan masyarakat agar lebih beragam,bergizi seimbang dan aman yaitu melalui Program Percepatan Penganekaragaman Konsumsi Pangan (P2KP) Peraturan Presiden Nomor 22 tahun 2009. Sebagai bentuk keberlanjutan Program Percepatan Penganekaragaman Konsumsi Pangan (P2KP) berbasis Sumber Daya lokal program tersebut di implementasikan atau diwujudkan melalui kegiatan Program Kawasan Rumah Pangan Lestari (KRPL) yang di lakukan melalui upaya pemberdayaan wanita. Hasil penelitian menunjukan bahwa Implementasi Program Kawasan Rumah Pangan Lestari di Desa Cinta Mekar Kecamatan Serangpanjang belum maksimal dalam pelaksanaannya,terutama dalam hal karakteristik dan kemampuan agen pelaksana dan kondisi lingkungan yang belum maksimal serta provider (Desa) yang belum mendukung.
\end{abstract}

Kata Kunci : Implementasi, keberlanjutan, kawasan rumah pangan lestari,

\section{Abstract}

In order to realize the fulfillment of the need for food for all people in an area, the availability of food becomes the main target in food policy for the government of a country. Therefore, in order to obtain sufficient reserves, the government has made a move to increase the diversity and quality of community food consumption to be more diverse and balanced nutrition safely through the Acceleration of Diversity Program for Food Consumption (P2KP) Presidential Regulation No. 22 of 2009. As a form of sustainability the Local Resource-based Food Consumption Diversification (P2KP) Acceleration Program is implemented or realized through the activities of the Sustainable Food Home Area Program (KRPL) which is carried out through 
efforts to empower women. The results showed that the implementation of the Sustainable Food Houses Area Program in Cinta Mekar Village, Serang panjang District had not been maximized in its implementation, especially in terms of the characteristics and capabilities of the implementing agents and the environmental conditions that were not optimal and the providers (villages) that were less supportive.

Keywords: implementation, sustainable, Food Houses Area,

\section{Pendahuluan}

Kebijakan publik mencakup semua aspek kehidupan berbangsa dan bernegara seperti ekonomi,politik, sosial, budaya serta pendidikan dan kesehatan. Dalam hal ini salah satu permasalahan penting yang dihadapi setiap negara dalam bidang ekonomi dan sosial yaitu masalah kemiskinan. Kita ketahui bersama bahwa kemiskinan merupakan masalah global yang menjadi musuh terbesar dari setiap negara.Jadi dalam hal tersebut diperlukan upaya atau strategi untuk mengatasi permasalahan tersebut. Kemiskinan mempunyai dampak negatif pada bidang kesehatan yaitu terjadinya gizi buruk dan minimnya konsumsi pangan yang mengakibatkan kelaparan Gizi buruk adalah bentuk terparah dari proses terjadinya kekurangan gizi yang dimana kondisi tersebut disebabkan karena rendahnya konsumsi energi dan protein (KEP) dalam makanan sehari-hari. Salah satu faktor penyebab yang mengakibatkan gizi buruk yaitu minimnya asupan gizi yang baik dengan rendahnya ketersedian cadangan pangan yang dapat mengakibatkan rentan rawan makan pada skala rumah tangga. Dengan demikian terdapat kaitan yang sangat erat antara keadaan gizi dengan konsumsi pangan.

Konsumsi pangan sangat dibutuhkan dan menjadi faktor utama masyarakat untuk hidup. Sehingga dapat dikatakan pangan merupakan kebutuhan yangmendasar bagi manusia untuk kelanjutan hidupnya, Oleh karena itu terpenuhinya pangan menjadi hak asasi bagi setiap orang. Dalam rangka mewujudkan pemenuhan kebutuhan akan pangan bagi seluruh masyarakat di suatu wilayah,maka ketersediaan pangan menjadi sasaran utama dalam kebijakan pangan bagi pemerintahan suatu negara. Menurut UU No.7 Tahun 1996 tentang Pangan menguraikan bahwa ketersediaan pangan yang lebih kecil dibandingkan kebutuhannya dapat menciptakan ketidak-stabilan ekonomi.Oleh karena itu untuk memperoleh cadangan yang cukup, maka pemerintah membuat satu gerakan untuk meningkatkan keragaman dan kualitas konsumsi pangan masyarakat agar lebih beragam,bergizi seimbang dan aman yaitu melalui Program Percepatan Penganekaragaman Konsumsi Pangan.

Percepatan Penganekaragaman Konsumsi Pangan (P2KP) merupakan upaya Implementasi dari Peraturan Presiden Nomor 22 tahun 2009 tentang Kebijakan Percepatan Penganekaragaman Konsumsi Pangan Berbasis Sumber Daya Lokal, yang tindak lanjuti oleh Peraturan Menteri Pertanian Nomor 43 tahun 2009 tentang Gerakan Percepatan Penganekaragaman Konsumsi Pangan Berbasis Sumber Daya lokal. Untuk mewujudkan penganekaragaman pangan diperlukan berbagai upaya secara sistematis 
dan terintregasi. Perpres ini ditindak lanjuti oleh Peraturan Menteri Pertanian Nomor 43 tahun 2009 tentang Gerakan Percepatan Penganekaragam Konsumsi Pangan Berbasis Sumber Daya Lokal. Peraturan Tersebut merupakan acuan untuk mendorong upaya Penganekaragaman Konsumsi Pangan dengan cepat melalui basis kearifan lokal serta kerjasama terintegrasi antara pemerintah, Pemerintah daerah dan masyarakat (Pedoman Pelaksanaan P2KP tahun 2015). Implementasi dari Perpres dan Permentan tersebut Kementrian Peratnian Melalui badan ketahanan pangan sejak tahun 2010 meluncurkan optimalisasi pemanfaatan melalui salah satu kegiatan Percepatan Penganekaragaman Konsumsi Pangan (P2KP) melalui program Peningkatan Disertivikasi Ketahanan Pangan masyarakat. Sebagai bentuk keberlanjutan Program Percepatan Penganekaragaman Konsumsi Pangan (P2KP) berbasis Sumber Daya lokal tahun 2010 maka sejak tahun 2014 program tersebut di implementasikan atau diwujudkan melalui 3 kegiatan Program besar yang diharapkan dapat meningkatkan kualitas konsusmi pangan masyarakat untuk membentuk pola konsusmi pangan yang baik. Dari 3 kegiatan Program yang ada,hanya Program Kawasan Rumah Pangan Lestari yang di lakukan melalui upaya pemberdayaan wanita. Program tersebut di atur dalam Peraturan Menteri Pertanian Nomor:15 Permentan/OT:140/2/2013 Tentang Peningkatan Disertvikasi dan Ketahanan Pangan bersama pedoman pelaksanaan P2KP dan pedoman umum KRPL.Dikabupaten subang implementasi kegiatan program Kawasan Rumah Pangan Lestari di laksanakan berdasarkan atas keputusan Peraturan Bupati Kabupaten Subang Nomor 16 tahun 211 tentang Percepatan Penganekaragaman konsumsi Pangan Melalui kegiatan Program Optimalisasi Pemanfaatan Pekarangan Kawasan Rumah Pangan Lestari (KRPL).

Berdasarkan Pedoman Umum KRPL Tahun 2015 Program Kawasan Rumah Pangan Lestari adalah kawasan pengembangan aneka tanaman,ternak (unggas),ikan secara terpadu di pekarangan.Tujuan Utama dari pengembangan KRPL adalah meningkatkan ketersediaan cadangan pangan dan penganekaragaman pangan,meningkatkan kualitas gizi keluarga,meningkatkan pendapatan keluarga dan menumbuh kembangkan ekonomi kreatif di setiap desa. Dan sasaran dari program KRPL yaitu seluruh desa dan kelurahan.di seluruh wilayah indonesia melalui kelompok wanita tani, dan pemberdayaan ibu-ibu rumah tangga yang tergabung dalam PKK desa, desa wisma sebagai pelaku dan anggota pekarangan minimal 15 orang untuk menumbuh kembangkan kebun bibit desa dan sarana penunjang lainnya.

Berdasarkan Ruang lingkup Program P2KP tahun 2013 Optimalisasi Pemanfaatan pekarangan melalui konsep kawasan rumah pangan lestari (KRPL) Optimalisasi pemanfaatan pekarangan dilakukan melalui upaya pemberdayaan wanita untuk mengoptimalkan manfaat pekarangan sebagai sumber pangan keluarga. Upaya ini di lakukan dengan membudidayakan berbagai jenis tanaman sesuai kebutuhan keluarga seprti umbi-umbian,sayuran,buah,serta budidaya ternak dan ikan sebagai tambahan untuk ketersediaan sumber karbohidrat,vitamin,mineral,dan protein bagi keluarga pada suatu lokasi kawasan perumahan/warga yang saling berdekatan. dengan demikian akan dapat terbentuk sebuah kawasan yang kaya akan sumber pangan yang di produksi sendiri dalam kawasan tersebut dari optimalisasi pekarangan. 
Pendekatan perkembangan ini dilakukan dengan mengembangkan pertanian berkelanjutan (Sustainable agriculture), antara lain dengan membangun kebun bibit dan mengutamakan sumber daya lokal di sertai dengan pemanfaatan pengetahuan lokal sehingga kelestarian alampun tetap terjaga.Implementasi kegiatan ini di sebut Kawasan Rumah Pangan Lestari ( KRPL).

Kegiatan Program Kawasan Rumah Pangan Lestari (KRPL) dengan pendampingan oleh penyuluh pendamping KRPL desa dan pendamping KRPL kabupaten/kota.serta di koordinasikan dengan aparat kabupaten/kota. Selain pemanfaatan pekarangan, juga diarahkan untuk pemberdayaan kemampuan kelompok wanita membudayakan pola konsumsi pangan yang beragam,bergizi seimbang dan aman (B2SA).Termasuk kegiatan usaha pengolahan pangan rumah tangga untuk menyediakan pangan yang lebih beragam. Kelompok sasaran Kegiatan Program Kawasan Rumah Pangan Lestari (KRPL) adalah kelompok wanita tani yang beranggotakan minimal 30 rumah tangga yang berdomisili berdekatan dalam satu desa sehingga membentuk kawasan. Setiap anggota wajib mengembangkan pemanfaatan pekarangan dengan menanam tanaman sumber pangan seperti sayur,buah,umbi ataupun memelihara ternak dan ikan. Tujuan dari program KRPL Selain sasarannya untuk kelompok wanita tani, Program ini tentu di tujukan untuk Kepentingan masyarakat untuk mencukupi ketersediaan pangan dan gizi di tingkat rumah tangga. Hasil dari usaha pekarangan ini di utamakan untuk di konsumsi oleh rumah tangga bersangkutan dan apabila berlebih dapat di bagikan kepada anggota kelompok atau secara bersama-sama di jual oleh kelompok. Program KRPL merupakan program dari seluruh desa dan kelurahan.di seluruh wilayah dalam hal ini salah satu provinsi yang menjadi pelaksanaan Program Kawasan Rumah Pangan Lestari adalah Provinsi Jawa Barat dan Kabupaten yang ada di provinsi Jawa Barat yang telah memberlakukan Program Kawasan Rumah Pangan Lestari (KRPL) diantaranya adalah Kabupaten Subang.

Di Kecamatan Serangpanjang pada tahun 2010 dengan dana APBN, KRPL dilaksanakan dengan sasaran 2 Desa yaitu: Desa Talagasari dan Desa Cijengkol dengan 2 kelompok wanita tani (KWT). Kemudian di kecamatan serangpanjang data tahun 2018 dana APBN dengan sasaran 2 Desa yaitu: Desa Cinta Mekar dan Desa Cijengkol dengan 2 kelompok wanita tani (KWT). Tahun 2018 dana APBD II dengan sasaran desa yaitu Desa Ponggang. Daerah yang menjadi target sasaran Program KRPL adalah desa rawan stunting di kecamatan serangpanjang salah satu desa yang mengalami rawan stunting adalah Desa Cinta Mekar, adanya program KRPL ini sangat penting salah satunya untuk pencegahan stunting dengan cara memenuhi kebutuhan pangan dan gizi keluarga dengan menerapkan KRPL si setiap rumah tangga. Berdsarkan hasil wawancara di Desa Cinta Mekar bahwa pelaksanaan program KRPL belum berjalan optimal hal ini dapat di lihat dari kesadaran serta partisipasi sebagian ibu-ibu yang ingin selalu instan lebih baik membeli dari pada menanam. Snagat sulit untuk merubah kebiasaan ini padahal keberadaan KRPL ini sangatlah penting untuk ketahanan pangan keluarga. 
Pelaksanaan Program KRPL di Desa Cinta Mekar Kecamatan Serangpanjang di jalanakan sesuai dengan aturan yang ada, tetapi dalam penerapannya masih mengalami beberapa kendala permasalahan seperti: kondisi Lingkungan belum mendukung program KRPL berjalan optimal terlihat dari faktor cuaca serta serangan hama dan lokasi atau media tanam masih terbatas, karakteristik dan Kemampuan agen pelaksana masih belum sesuai dengan harapan masyarkat terlihat dari pengelola KRPL KWT mekar wangi kurang menguasai tekhnik budidaya tanaman dan kurang aktifnya KWT mekar wangi dalam budidaya tanaman, dan hubungan antar Organisasi masih belum sesuai harapan kelompok wanita tani (KWT) terlihat dari Pemerintah setempat kurang mendukung KWT dalam pelasanaan program KRPL berjalan optimal.

\section{Kerangka Teori}

\section{Pengertian Kebijakan Publik}

Pada dasarnya terdapat banyak batasan atau definisi mengenai apa yang di maksud dengan kebijakan publik (Public Policy). Masing-masing definisi tersebut memberi penenakanan yang berbeda-beda, perbedaan ini timbul karena masingmasing ahli mempunyai latar belakang yang berbeda-beda. Sementara di sisi lain,pendekatan dan model yang digunakan oleh para ahli pada akhirnya akan menentukan bagaimana kebijakan publik tersebut didefinisikan. Menurut Winarno dalam bukunya "Kebijakan dan Proses Kebijakan Publik", yang mempergunakan istilah kebijakan. Kebijakan di gunakan untuk menunjuk perilaku seseorang aktor (misalnya seorang pejabat,suatu kelompok,maupun suatu lembaga pemerintah) atau sejumlah aktor dalam suatu bidang kegiatan tertentu. Sementara menurut Jones, istilah kebijakan tidak hanya digunakan dalam praktik sehari-hari namun digunakan untuk menggantikan kegiatan atau keputusan yang sangat berbeda. Berkaitan dengan pengertian kebijakan tersebut, Friedrich yang dikutip oleh Winarno (2002 :16) memberikan pengertiannya sebagai berikut: " Kebijakan sebagai suatu arah tindakan yang diusulkan oleh seseorang,kelompok atau pemerintah dalam suatu lingkungan tertentu,yang memberikan hambatan-hambatan dan kesempatan terhadap kebijakan yang diusulkan untuk menggunakan dan mengatasi dalam rangka mencapai suatu tujuan atau merealisasikan suatu sasaran atau suatu masud tertentu". Istilah kebijakan ini lebih tertuju pada kebijakan publik (Publik Policy) yaitu kebijakan negara, kebijakan yang dibuat negara.Kebijakan publik dapat juga berarti serangkaian tindakan yang ditetapkan dan dilaksanakan atau tidak dilaksanakan oleh pemerintah yang mempunyai tujuan tertentu demi kepentingan seluruh masyarakat. Bentuk kebijakan publik itu bisa berupa undang-undang atau peraturan daerah (perda) dan yang lain. Menurut Nakamura dan Smalwood, Kebijakan publik berarti serangkaian intruksi dari para pembuat keputusan kepada pelaksana untuk mencapai tujuan tersebut (Santoso,1990:5). Nakamura dan Samalwood melihat kebijkan publik dalam ketiga lingkungan pelaksanaan kebijakan dan lingkungan penilaian kebijakan. Woll sebagaimana dikutip Tangkilisan (2003:2) menyebutkan bahwa kebijakan publik ialah sejumlah aktivitas pemerintah untuk memecahkan masalah di tengah masyarakat,baik secara langsung maupun melalui berbagai lembaga yang mempengaruhi kehidupan 
masyarakat. Edwards III dan Sharkansky dalam Suwitri (2008:10) mendefinisikan kebijakan publik sebagai "suatu tindakan pemerintah yang berupa program-program pemerintah untuk pencapaian sasaran atau tujuan. Menurut Thomas R.Dye dalam Howlett dan Ramesh (2005:2), kebijakan publik adalah "segala yang dikerjakan pemerintah, mengapa mereka melakukan, dan perbedaan yang dihasilkannya (what government did, why they it and that waht differences it makes)". Dalam pemahaman bahwa "keputusan" termasuk juga ketika pemerintah memutuskan untuk "tidak memutuskan" atau memutuskan untuk "tidak mengurus" suatu isu, maka pemahaman ini juga merujuk pada definisi Thomas R.Dye dalam Tilaar dan Nugroho (2008:185) yang mengatakan bahwa kebijakan publik merupakan "segala sesuatu yang dikerjakan dan tidak dikerjakan oleh pemerintah. Sulaiman (1998:24) Kebijakan publik itu adalah sebagai suatu proses yang mengandung berbagai pola aktivitas tertentu dan merupakan seperangkat keputusan yang bersangkutan dengan tindakan untuk mencapai tujuan dalam beberapa cara yang khusus. Dengan demikian, maka konsep kebijakan publik berhubungan dengan tujuan. Suradinata (1993:19) Mendefinisikan kebijakan publik sebagai kebijakan negara/pemerintah adalah kebijakan yang dikembangkan oleh badan-badan atau lembaga dan pejabat pemerintah. Kebijakan negara dalam pelaksanaannya meliputi beberapa aspek, berpedoman pada ketentuan yang berlaku, berorientasi pada kepentingan umum dan maa depan, serta strategi pemecahan masalah yang tertarik. Kartasasmita dalam Widodo (2001: 180) mengemukakan bahwa: "kebijakan publik adalah apa yang pemerintah katakan dan lakukan, atau tidak lakukan, kebijakan merupakan serangkaian tujuan dan sasaran dari program-program pemerintah (whatt government say and do, or not to do. It is goods or pupose of government programs). Irfan Islamy (2001:17) mengemukakan: "kebijakan sebagai suatu taktik dan strategi untuk mencapai suatu tujuan oleh karena itu suatu kebijakan memuat tiga elemen yaitu: Identifikasi dari tujuan yang ingin dicapai, taktik dan strategi dari berbagai langkah untuk mencapai tujuan yang diinginkan dan penyediaan berbagai input untuk memungkinkan pelaksanaan secara nyata dari strategi atau taktik.

Menurut James Anderson, Mengatakan bahwa :" Public Policy are those policies developed by govermental bodies and officials " (kebijakan publik adalah kebijakankebijakan yang di kembangkan oleh badan-badan dan pejabat-pejabat pemerintah). Menurut Anderson implikasi dari pengertian kebijakan publik tersebut adalah:

1) Bahwa kebijakan publik selalu mempunyai tujuan tertentu atau merupakan tindakan yang berorientasi pada tujuan.

2) Bahwa kebijakan itu berisi tindakan-tindakan atau pola-pola tindakan pejabatpejabat pemerintah.

3) Bahwa kebijakan itu adalah apa yang benar-benar dilakukan oleh pemerintah,jadi bukan merupakan apa pemerintah bermaksud akan melaukan sesuatu atau menyatakan akan melaukan sesuatu.

4) Bahwa kebijakan publik itu bersifat positif dalam arti merupakan beberapa bentuk tindakan pemerintah mengenai suatu masalah tertentu atau bersifat 
negatif dalam arti merupakan keputusan pejabat pemerintah untuk tidak melakukan sesuatu.

5) Bahwa kebijakan pemerintah dalam arti yang positif didasarkan atau selalu dilandaskan pada peraturan perundang-undagan dan bersifat memaksa (otoritatif).

Menurut David Easton yang (dikutip oleh Dye,1981) mengatakan ketika pemerintah membuat kebijakan publik,ketika itu pula pemerintah mengalokasikan nilai-nilai kepada masyarakat, karena setiap kebijakan mengandung seperangkat nilai di dalamnya. Menurut Laswell dan Kaplan (dikutip oleh Dye, 1981) berpendapat bahwa kebijakan publik hendaknya berisi tujuan,nilai-nilai, dan praktika-praktika sosial yang ada dalam masyarakat. Ini berarti kebijakan publik tidak boleh bertentangan dengan nilai-nilai dan praktika-praktika sosial yang ada dalam masyarakat. Ketika kebijakan publik berisi nilai-nilai yang bertentangan dengan nilai-nilai yang hidup dalam masyarakat,maka kebijakan publik tersebut akan mendapatkan resistensi ketika diimplementasikan.Sebaliknya, suatu kebijakan publik harus mampu mengakomodasi nilai-nilai dan praktika-praktika yang hidup dan berkembang dalam masyarakat. Dari pengertian kebijakan publik yang di uraikan diatas dapat disimpulkan bahwa:

1) Kebijakan publik dibuat oleh pemerintah yang berupa tindakan-tindakan pemerintah;

2) Kebijakan publik baik untuk melakukan atau tidak melakukan sesuatu itu mempunyai tujuan tertentu;

3) Kebijakan publik ditujukan untuk kepentingan masyarakat dan hendaknya setiap kebijakan publik tidak boleh bertentangan dengan nilai-nilai dan praktika-praktika sosial dalam masyarakat.

\section{Jenis Kebijakan Publik}

Menurut James E. Anderson, kebijakan publik dapat di kelompokkan sebagai berikut:

1) Subtantive Policies and Procedural Policies

Subtantive Policies adalah kebijakan yang dilihat dari subtansi masalah yang di hadapi oleh pemerintah, Misalnya,kebijakan politik luar negeri, kebijakan dibidang pendidikan, kebijakan ekonomi,dan sebagainya. Dengan demikian yang menjadi tekanan dari subtantive policies adanya pokok masalahnya (subject matter) kebijakan. Procedural Policies adalah suatu kebijakan yang dilihat dari pihak-pihak mana saja yang terlibat dalam perumusan kebijakan serta cara bagaimana suatu kebijakan publik diimplementasikan.

2) Distributive, Redistributive, and Self Regulatory Policies

Distributive Policies adalah suatu kebijakan yang mengatur tentang pemberian pelayanan atau keuntungan bagi individu-indidu,kelompokkelompok,perusahaan-perusahaan atau masyarakat tertentu. Redistributive Policies adalah kebijakan yang mengatur tentang pemindahan alokasi 
kekayaan,pemilikan,atau hak-hak diantara kelas-kelas dan kelompokkelompok penduduk. Self Regulaory Policies adalah kebijakan yang mengatur tentang pembatasan atau pelarangan perbuatan atau tindakan bagi seseorang atau kelompok orang.

3) Material Policies

Material policies adalah kebijakan-kebijakan tentang pengalokasian atau penyediaan sumber-sumber material yang nyata bagi para penerimanya,atau mengenakan beban-beban bagi mereka yang mengalokasikan sumber-sumber material tersebut.

4) Publik Goods and Private Goods Policies

Publik Goods Policies adalah suatu kebijakan yang mengatur tentang penyediaan barang-barang dan pelayanan-pelayanan untuk kepentingan orang banyak. Private Goods Policies merupakan kebijakan-kebijakan tentang penyediaan barang-barang atau pelayanan untuk kepentingan perorangan yang tersedia di pasar bebas, dengan imbalan biaya tertentu.

\section{Sifat Kebijakan Publik}

Menurut Winarno,sifat kebijakan bisa diperinci menjadi beberapa kategori, yaitu:

1.) Tuntutan Kebijakan (policy demands) adalah tuntutan-tuntan yang dibuat oleh aktor-aktor swasta atau pemerintah, ditujukan kepada pejabat-pejabat pemerintah atau sistem politik.

2.) Keputusan kebijakan (policy decisions) didefinisikan sebagai keputusankeputusan yang dibuat oleh pejabat-pejabat pemerintah yang mengesahkan atau memberi arah dan substansi kepada tindakan-tindakan kebijakan publik. Yang termasuk dalam kegiatan ini adalah menetapkan undang-undang, memberikan perintah-perintah eksekutif atau pernyataan-pernyataan resmi, mengumumkan peraturan-peraturan administratif atau membuat interprestasi yuridis terhadap undang-undang.

3.) Pernyataan kebijakan (policy statments) adalah pernyataan-pernyataan resmi atau artikulasi-artikulasi kebijakan publik. Yang termasuk kategori ini adalah undang-undang legislatif, perintah-perintah dan dekrit presiden, peraturanperaturan administratif dan pengadilan,maupun pernyataan-pernyataan atau pidato-pidato pejabat pemerintah dan apa yang akan dilakukan untuk mencapai tujuan itu.

4.) Hasil kebijakan (policy outputs) lebih merujuk ke manisfestasi nyata dari kebijakan publik, hal-hal yang sebenarnya dilakukan menurut keputusankeputusan dan pernyatan-pernyataan kebijakan.

5.) Dampak kebijakan (policy outcomes) lebih merujuk pada akibat-akibatnya masyarakat, baik yang diinginkan yang berasal dari tindakan atau tidak adanya tindakan pemerintah. Definisi sifat kebijakan publik diatas adalah jelas bahwa sebenarnya kebijakan itu tidak hanya dirumuskan lalu dibuat dalam suatu bentuk positif seperti undang-undang dan kemudian tidak dilaksanakan atau diimplementasikan, tetapi sebuah kebijakan publik harus 
dilaksanakan atau diimplementasikan agar mempunyai dampak atau tujuan yang diinginkan dan kemudian dievaluasi pelaksanaanya.

\section{Model Implementasi Kebijakan}

Menurut Dunn, tindakan implementasi dapat di bedakan ke dalam "policy inputs and policy process". Policy input berupa masukan sumber daya, sedangkan policy process bertalian dengan kegiatan administratif organisasional yang membentuk transformasi masukan kebijakan kedalam hasil-hasil (outputs) dan dampak (impact) kebiajakan. Model yang dikembangkan oleh G shabbir Cheema dan Dennis A. Rondinelli (1983). Menurut Cheema dan Rondinelli Terdapat lima variabel proses implementasi suatu program yaitu:

1) kondisi lingkungan

2) Hubungan antar organisasi

3) Sumber daya organisasi

4) Karakteristik dan kapabilitas instansi pelaksana

5) Kinerja dan dampak.

Model yang dikembangkan oleh Donald S. Van Meter dan Carl E. Van Horn (1975) menurut Meter dan Horn ada enam model proses implementasi kebijakan yaitu:

1) Ukuran dan tujuan kebijakan

2) Sumberdaya

3) Hubungan antar organisasi dan kegiatan pelaksanaan

4) Karakteristik agen pelaksana

5) Lingkungan ekonomi,sosial dan politik

6) Disposisi pelaksana

\section{Faktor - faktor yang Mempengaruhi Keberhasilan Implementasi Kebijakan Publik} Implementasi kebijakan akan efektif apabila birokrasi pelaksanaannya mematuhi apa yang telah digariskan dalam peraturan. Islamy mengatakan bahwa, “ suatu kebijakan negara atau pemerintah akan menjadi efektif bila dilaksanakan dan mempunyai dampak positif bagi anggota-anggota masyarakat tersebut bersamaan dengan apa yang diinginkan oleh pemerintah atau negara. Dengan demikian, implementasi kebijakan akan efektif dan berdampak positif bagi masyarakat apabila dalam pelaksanaannya terjadi kesesuaian yang terjadi di dalam masyarakat dengan apa yang diinginkan oleh pemerintah. Hal ini dimaksudkan untuk mempermudah pemerintah dalam mengevaluasi keberhasilan atau kegagalan dalam mengimplementasikan kebijakan tersebut. Keberhasilan implementasi kebijakan akan ditentukan oleh banyak variabel atau faktor, dan masing-masing variabel tersebut saling berhubungan satu sama lain. Menurut Teori Implementasi Kebijakan Program G Shabbir Cheema dan Dennis A.Rondinelli terdapat kerangka konseptual yang dapat digunakan untuk analisis implementasi program-program pemerintah yang bersifat denstralistis. terdapat empat variabel yang dapat mempengaruhi kinerja dan dampak suatu program yaitu: 
a) Kondisi lingkungan

b) Mencakup lingkungan sosio kultural serta keterlibatan penerima program.

c) Hubungan antar organisasi

d) Dalam banyak program,implementasi sebuah program perlu dukungan dan koordinasi dengan instansi lain. Untuk itu diperlukan koordinasi dan kerjasama antar instansi untuk keberhasilan suatu program.

e) Sumberdaya organisasi untuk implementasi program

f) Untuk implementasi program implementasi kebijakan perlu di dukung sumberdaya baik manusia (human resources) maupun sumberdaya nonmanusia (non human resouces).

g) Karakteristik dan kemampuan agen pelaksana

h) Mencakup struktur birokrasi,norma-norma dan pola-pola hubungan yang terjadi dalam birokrasi yang semuanya itu akan mempengaruhi implementasi suatu program.

\section{Metode Penelitian}

Penelitian ini merupakan penelitian kualitatif yaitu penelitian yang menghasilkan data deskriptif berupa gambaran dan kata-kata tertulis atau lisan dari informan serta perilaku yang diamati. Strategi penelitian yang digunakan peneliti adalah eksplorasi terhadap proses, aktivitas, dan pristiwa (Creswell,2010).Peneliti menggunakan metode penelitian kualitatif dengan tujuan ingin menggali lebih dalam dari berbagai sumber dan informan mengenai pelaksanaan Implementasi Program Kawasan Rumah Pangan Lestari di Dinas Ketahanan Pangan Kabupaten Subang. Pemilihan informan ini dilakukan dengan menggunakan teknik snowball. Pemilihan informan yang berdsarkan pertimbangan tertentu, misalnya orang yang paling mengetahui atau mempunyai otoritas pada objek atau situasi yang akan akan diteliti. Sehingga informan tersebut mampu memberikan petunjuk dan referensi kemana saja peneliti dapat melakukan pengumpulan data (Sugiyono, 2008).

Informan yang menjadi narasumber pengumpulan data primer dalam penelitian ini adalah:

1) Penyuluh Pendamping KRPL Desa, Informan ini di pilih karena dapat memberikan data dan informasi tentang program kawasan rumah pangan lestari di Desa Cinta Mekar.

2) Kelompok wanita tani (KWT), informan ini di pilih karena dapat memberikan informasi dan data tentang pencapaian kegiatan pengelolaan program kawasan rumah pangan lestari di Desa Cinta Mekar.

3) Masyarakat, informan ini di pilih karena sebagai penerima manfaat program kawasan rumah pangan lestari di Desa Cinta Mekar. 


\section{Hasil dan Pembahasan}

\section{Gambaran Umum Desa Cinta Mekar dan Kebijakan Rumah Pangan Lestari (KRPL)}

Cinta Mekar adalah Desa yang berada di Kecamatan Serangpanjang Kabupaten Subang Jawa Barat Indonesia dengan jumlah penduduk 2.434 jiwa (2013) Wilayah Cinta Mekar meliputi 4 dusun, $8 \mathrm{Rw}$ dan 16 RT. Cinta Mekar merupakan salah satu desa dengan nama terunik, nama tersebut ternyata merupakan singkatan dari nama ke empat dusun yang berada di cinta mekar, CI untuk Cimute, Ta untuk Tangkil, Me untuk Malingping, dan kar untuk Karapyak. Dahulu tingkat pembangunan di Cinta Mekar tergolong lambat terutama dari sisi pendidikan dan ekonomi. Namun pada tahun 2003 perubahan mulai terasa di desa ini saat warganya secara swadaya mulai membangun dan mengelola pembangkit listrik Mikrohidro sebesar 120 kilowatt yang memanfaatkan aliran sungai Ciasem, dampak positif pun mulai dirasakan warga yaitu dengan mendapat manfaat lain dari masuknya listrik kerumah-rumah warga. Sebelum pemekaran Desa Cinta Mekar ini masuk ke dalam wilayah Kecamatan Sagalaherang.

Visi Desa Cinta Mekar adalah Terwujudnya Desa Cintamekar yang Aman dan Sehat Cerdas dan berahlaq mulia serta Takwa terhadap Allah yang maha Esa. Adapun Misi Desa Cinta Mekar yaitu : Mewujudkan keamanan dan ketertiban Seluruh Lingkungan; Meningkatkan Pelayanan yang baik Terhadap Seluruh Masyarakat; Mengedepankan Kejujuran,Keadilan, Transparans Terhadap Mayarakat; dan Meningkatkan Kehidupan Yang Harmonis, Toleransi Saling Menghormati.

Kawasan Rumah Pangan Lestari (KRPL adalah suatu program kegiatan yang mengusahakan kawasan rumah penduduk dengan memanfaatkan pekarangan secara intensif untuk dimanfaatkan dengan berbagai sumber daya lokal secara bijaksana yang menjamin kesinambungan penyediaan bahan pangan rumah tangga yang berkualitas dan beragam. Berdasarkan Petunjuk Teknis KRPL 2018 Keputusan Menteri Pertanian Republik Indonesia Nomor 62/Kpts/RC.110/J/12/2017 Tentang Petunjuk Teknis Optimalisasi Pemanfaatan Lahan Pekarangan Melalui Kawasan Rumah Pangan Lestari. Optimalisasi pemanfaatan lahan pekarangan melalui Kawasan Rumah Pangan Lestari merupakan prioritas dalam rangka mempercepat diservikasi pangan dan memperkuat kebutuhan pangan dan gizi keluarga. Pelasanaan Program Kegiatan KRPL TAHUN 2018 di biayai dengan dana bantuan Pemeintah melalui dana dekonsentrasi di provinsi. Melalui Program ini di harapkan dapat meningkatkan kualitas konsumsi pangan masyarakat untuk membentuk pola konsumsi pangan yang baik. KRPL juga dilaksanakan dalam rangka mendukung program pemerintah untuk penurunan kemiskinan melalui kegiatan padat karya,penanganan daerah stunting, serta penanganan daerah rentan rawan pangan. Untuk mempercepat akselerasi gerakan pemanfaatan pekarangan melalui konsep KRPL, perlu dijalin kerja sama kemitraan dengan pihak swasta,antara lain berupa Corporate Social Responsibility (CSR)Program Kemitraan dan Bina Lingkungan (PKBL). Kerjasama tersebut dapat dilakukan 2018 baik bidang pangan maupun bidang lainnya seperti pendidikan dengan sosialisasi kepada anak usia dini atau masyarakat lainnya. Pelaksanaan kegiatan KRPL perlu di lakukan secara intregitasi dengan kegiatan lainnya, baik dalam pelaksanaan maupun pembiayaannya. Gubernur dan Bupati/Walikota seabagai integrator utama di 
daerah,memiliki peranan penting dalam mengkoordinasikan kegiatan KRPL, khususnya terhadap Organisasi Perangkat Daerah (OPD) sebagai agen pembawa perubahan (agent of change). Tujuan Program KRPL yaitu:

1) Memberdayakan rumah tangga dan masyarakat dalam penyediaan sumber pangan dan gizi melalui optimalisasi pemanfaatan pekarangan dan lahan sekitar tempat tinggal.

2) Meningkatkan kesadaran, peran, dan partisipasi masyarakat dalam mewujudkan pola konsumsi pangan yang beragam, bergizi seimbang dan aman (B2SA).

Terlaksananya kegiatan KRPL di 2.300 kelompok baru di 33 provinsi dengan prioritas daerah rentan rawan pangan berdasarkan Food Security and Vulnerability Atlas (FSVA)/Peta Ketahanan dan Kerawanan Pangan serta kabupaten prioritas penanganan Stunting. Indikator keberhasilanya adalah aIndikator Output: Jumlah KRPL yang dikembangkan sebanyak 2300 kelompok. Indikator Outcome: Meningkatnya frekuensi konsumsi sayuran, buah dan protein hewani pada kelompok KRP.Indikator Manfaat: Meningkatnya skor PPH. Kosep kegiatan KRPL yakni Potensi luas lahan pekarangan dan lahan sekitar tempat tinggal yang belum dimanfaatkan relatif besar untuk dapat dimanfaatkan sebagai sumber pangan keluarga. Masyarakat berperan dalam peningkatan pemanfaatan pekarangan sebagai sumber pangan dan gizi keluarga. Perempuan di lingkungan rumah tangga merupakan penentu/pengambil keputusan dalam pemenuhan pangan dan gizi keluarga dan anak-anak sebagai generasi penerus. Untuk itu dalam kegiatan KRPL menggunakan konsep Pemberdayaan Keluarga dan masyarakat dengan melibatkan seluruh anggota keluarga dan anggota kelompok (padat karya). Strategi Pelaksanaannya adalah

Implementasi Program Kawasan Rumah Pangan Lestari (KRPL) di Desa Cinta Mekar (Kelompok Wanita Tani Mekar Wangi) Serangpanjang

Program Kawasan Rumah Pangan Lestari merupakan Program Pemerintah dalam rangka mempercepat penganekaragaman pangan dan memperkuat ketahanan pangan untuk mendukung pemerintah untuk penanganan stunting, Bedah, Kemiskinan, Rakyat Sejahtera (Bekerja) penanganan wilayah rentan rawan pangan dan pengembangan daerah perbatasan. Berikut pemaparan mengenai implementasi program KRPL di Desa Cinta Mekar (Kelompok Wanita Tani Mekar Wangi) Kecamatan Serangpanjang berdasarkan kerangka konsep yang peneliti adopsi dari G. Shabbir Cheema \& Dennis A. Rondinelli.

\section{Kondisi Lingkungan}

Kondisi Lingkungan sangat mementukan keberhasilan pencapaian tujuan dari implementasi program Kawasan Rumah Pangan Lestari khususnya di Desa Cinta Mekar Serangpanjang. Hal yang perlu di perhatikan guna menilai kinerja implementasi program dalam prespektif yang ditawarkan oleh G Shabbir Cheema dan Dennis A. Rondinelli adalah sejauh mana kondisi lingkungan turut mendorong keberhasilan kebijakan publik yang telah di tetapkan. Lingkungan yang tidak kondusif dapat 
menjadi faktor dari kegagalan kinerja implementasi program. Karena itu, upaya untuk mengimplementasikan program harus pula memperhatikan kekondusifan kondisi lingkungan eksternal. Kondisi-kondisi lingkungan juga akan berpengaruh pada kecenderungan para pelaksana.Kondisi-kondisi lingkungan mungkin menyebabkan para pelaksana suatu kebijakan tanpa mengubah pilihan-pilhan probadi mereka tentang kebijakan itu. Akhirnya, faktor-faktor lingkungan ini di pandang mempunyai pengaruh langsung pada pemberian-permberian kinerja pelaksana dalam implementasi program. Kondisi-kondisi lingkungan mungkin memperbesar atau membatasi pencapaian, sekalipun kecenderungan para pelaksana dan kekuatan lain dalam model ini juga mempunyai pengaruh terhadap implementasi program. Berikut hasil kutipan wawancara dari informan Penyuluh Pendamping Desa Cinta Mekar terkait dukungan eksternal terhadap pelasanaan program KRPL: “... Paling ya.. masalah lahan yang masih terbatas sehingga sehingga kita masih kekurangan tempat sebagai media tanam untuk menyimpan polibag, demplot, akhirnya jumlah polibag, dan demplot untuk menyimpan tanaman pun masih kurang itu juga bisa mengurangi jumlah KRPL nya.." Berikut kutipan hasil wawancara dengan informan ketu KWT mekar wangi Desa Cinta Mekar: “..Nah cuaca juga sangat mempengaruhi, kalau cuaca buruk misalnya di musim hujan ya tanaman banyak yang rusak, mati karena kelebihan air mungkin, kita jadi tidak bisa panen, kalau di musim kemarau juga sama tanaman ada yang rusak, mati, karena kekeringan apalagi kalau rusak semua, kita harus nanam ulang.." " Kadang juga adanya hama yang menyebabkan tanaman rusak dan menyebabkan gagal panen juga jadi yaaa..malah rugi..." Berikut kutipan hasil wawancara dengan infroman Masyarakat Desa Cinta Mekar: "Iya kalau dari lingkungan yang saya lihat juga ya itu hama sama keterbatasan lahan masih menjadi kendala jadi jumlah polibag nya tidak tertlau banyak karena itu tidak ada lahan.." Berdasarkan hasil anlalisis kutipan wawancara dengan infroman diatas bahwa kondisi lingkungan masih kurang memadai dan mendukung untuk pelaksanaan program KRPL di Desa Cinta Mekar melihat dari hasil wawancara dengan ke 3 informan diatas bahwa keterbatasan lahan sebagai media tanam yang masih kurang serta faktor cuaca buruk yang dapat mempengaruhi pelaksanaan program KRPL kurang optimal juga serta dari masalah kondisi lingkungan lainnya yaitu masalah hama yang memang banyak merusak tanaman dan menyebabkan kegegalan panen. Dimana Pencapaian program KRPL pun kurang berjalan dengan baik.. Jika memperhatikan teori G. Shabbir Cheema dan Dennis A. Rondinelli bahwa kondisi lingkungan sangat mempengaruhi tercapainya tujuan implementasi program KRPL di Desa Cinta Mekar jika kondisi lingkungan nya tidak mendukung maka program tidak akan bisa berjalan dengan baik. Dapat disimpulkan dari analisis di atas keterbatasan lahan masih menjadi kendala untuk mendukung pelaksaan program KRPL berjalan optimal.

\section{Hubungan Antar Organisasi}

Pelaksanaan langsung dilapangan untuk program KRPL adalah Desa sebagai fasilitator dan Dinas Ketahanan Pangan sebagai implementor program Kawasan Rumah Pangan Lestari. Komunikasi dalam kerangka penyampaian informasi kepada 
para pelaksana program tentang apa menjadi standar dan tujuan konsisten dan seragam (consistency and uniformity) dari berbagai sumber informasi. Disamping itu, koordinasi merupakan mekanisme yang ampuh dalam implementasi program. Semakin baik koordinasi di antara pihak-pihak yang terlibat dalam implementasi program, maka kesalahan akan semakin kecil, demikian sebaliknya. Koordinasi dan komunikasi yang terjalin antara Desa Cinta Mekar, Kelompok Wanita Tani mekar wangi dan Dinas Ketahanan Pangan dapat di lihat dari hasil kutipan wawancara dengan informan ketua KWT mekar wangi Desa Cinta Mekar: "Nah Selama ini di bisa dikatakan tidak ada respon dari pihak desa kepada kita melihat dari pihak desa justru seperti tidak memberikan apresiasi dan dukungan nya untuk pelaksaan KRPL. Jadi hanya oleh kita saja kelompok...seharusnya memang bisa ikut mendukung juga untuk pelaksanaan KRPL ini...”. “.... kalau dengan pendamping teknis KRPL kita bekerjasama dengan baik untuk mengelola KRPL pendamping juga banyak membantu dan memotivasi kita kelompok...". "Nah kalau dari pihak dinas ada namanya monitoring tiap 3 bulan sekali selain ikut mengawasi juga ada kunjungan pemeriksaan dari dina ke desa.." Berikut kutipan hail wawancara dengan informan Penyuluh Pendamping Desa Cinta Mekar : ".kalau saya selaku pendamping tentu peran saya ikut mengawasi dan memberikan motivasi serta membantu dan juga mendukung KWT terutama ibu-ibu dalam pelaksanaan KRPL ini agar bisa berjalan sesuai petunjuk teknis.." "saya selaku pendamping memotivasi KWT dengan meningkatkan kesadaran dan memberikan semangat serta merubah kebiasaan, pola pikir ibu-ibu yang selalu ingin instan dari pada cape-cape menanam.. memang masih sulit untuk merubah kebiasaan ini dari ibuibu.."Berikut kutipan hasil wawancara dengan informan Masyarakat Desa Cinta Mekar: "Kalau menurut saya yang terlihat memang pihak desa Seperi kurang mendukung ya jadi paling sosialisasi kepada kia juga dari Dinas Ketahanan pangan dan dari KWT nya aja paling.." Berdasarkan hasil kutipan wawancara dengan informan di atas jika melihat hasil wawancara dengan ke 3 informan ada kesamaan mengatakan bahwa kurang adanya dukungan dari pemerintah setempat untuk pelaksanaan program KRPL sehingga hubungan antar KWT dengan pihak setempak belum sepenuhnya mendukung program KRPL berjalan optimal. Jika memperhatikan teori G Shabbir Cheema \& Dennis .A .Rondinelli dalam banyak program,implementasi sebuah program perlu dukungan dan koordinasi dengan instansi lain. Untuk diperlukan koordinasi dan kerjasama anatar instansi untuk keberhasilan suatu program. Berdasarkan hasil analisis di atas dapat di simpulkan pemerintah setempat kurang merepon dan kurang memperhatikan KWT untuk pelaksanaan program KRPL sehingga masih belum berjalan dengan baik.

\section{Sumber Daya Organisasi Untuk Implementasi Program Sumber Daya Manusia}

Aspek Pelaksanaan Program KRPL yang lain adalah SDM pelaksana di Desa yang terdiri dari pengelola dan Penyuluh Pendamping. Pengelola program KRPL adalah kelompok wanita tani (KWT) Setiap desa terdiri dari 1 KWT dengan jumlah anggota $30-40$ orang yang mengelolanya, serta 1 penyulung pendamping yang 
berperan sebagai pengawasan (controlling) dan pemberian motivasi kepada KWT. Berdasarkan hasil wawancara dengan penyuluh pendamping Desa Cinta Mekar mengenai kecukupan anggota pengelola KRPL di Desa Cinta Mekar yang kutipannya sebagai berikut: "Dengan jumlah anggota kelompok yang mencapai 30-40 orang ini menurut saya sudah cukup belum lagi di tambah ibu-ibu masyarakat yang bukan anggota tetapi ada juga yang mau ikut melaksanakan program ini depan pekarangannya dari kami mungkin hanya memfasilitasi saja.. nah untuk pelaksaan KRPL sendiri itu ada dua tahap ya.. yang pertama penumbuhan dan yang kedua pengembangan adi yang 30 anggota untuk tahap pertama dan yang 40 untuk tahap kedua jadi ya.. sudah cukup memadai". Berikut kutipan hasil wawancara dengan informan Ketua KWT mekar wangi Desa Cinta Mekar: "Ya.. semua jumlah anggota KWT itu ada 40 orang terdiri dari saya sebagai ketua, ada sekretaris dan bendahara nah sisanya anggota.." Berikut kutipan hasil wawancara dengan informan Masyarakat Desa Cinta Mekar: "Melihat dari jumlah anggota ibu-ibu KWT nya sih itu sudah cukup banyak ya yang mengelolanya... di tambah kita juga masayarakat.." Berdasarkan kutipan hasil wawancara di atas ke 3 informan mengatakan bahwa kecukupan sumber daya manusia nya sudah memadai dari banyak anggota Kelompok Wanita Tani (KWT) yang mengelolanya dengan di tambah peran masyarakat khususnya ibu-ibu juga sudah bisa dikatakan cukup untukpelaksanaan Program KRPL berjalan baik. Jika memperhatikan teori G Shabbir Cheema dan Dennis A.Rondinelli untuk implementasi program implementasi kebijakan perlu di dukung sumber daya baik manusia (human resources) maupun sumber daya non-manusia (non human resources). Berdasarkan hasil analisis di atas dapat di simpulkan bahwa dana bantuan pemerintah sudah cukup mendukung program KRPL.

\section{Sumber Daya Finansial}

Sumber pembiayaan KRPL berasal dari dana bantuan pemerintah untuk pencairan dana KRPL di ambil melalui rekening kelompok wanita tani karena dana langsung masuk ke rekening kelompok. Untuk mengetahui lebih dalam mengenai sumber pembiayaan program KRPL di Desa Cinta Mekar Kecamatan serangpanjang, Peneliti memperoleh data dari hasil wawancara dnegan informan ketua KWT mekar wangi Desa Cinta Mekar yang kutipannya sebagai berikut: " untuk sumber dana program KRPL itu sendiri berasal dari dana bantuan pemerintah yaitu dana dekonsentrasi dari provinsi jadi langsung dari pusat ya.. dan danannya pun langsung masuk ke rekening kelompok jadi di pegang langsung oleh kelompok untuk pencaiarannya pun hanya bisa di lakukan oleh kelompok saja.."...."untuk dana pembiayaan KRPL itu sudah cukup ya.. menurut saya jadi kita memanfaatkan dana tersebut sebaik-baiknya untuk keperluan saran dan prasarana seperti kebun bibit,demplot,polibag dll." Berikut kutipan wawancara dengan informan Penyuluh Pendamping Desa Cinta Mekar:" untuk dana bantuan dari pemerintah itu sudah cukup untuk pembiayaan program KRPL.karena untuk dana sendiri ada tiga tahap ada dana APBD I BPTP,APBD II Pemda DKP, dan APBD DKP.." Berikut hasil kutipan wawancara dengan informan Masyarakat Desa Cinta Mekar: "Menurut saya dana dari 
pemerintah untuk biaya Program KRPL itu sudah cukup dananyapun cukup besar..." Berdasarkan hasil analisis dengan 3 informan di atas dapat di kataka bahwa sumber daya finansial sudah cukup memadai untuk pembiayaan Pogram KRPL. Dilihat dari kutipan wawancara informan 2 bahwa untuk pembiayaan KRPL itu terdapat dana untuk tiga tahap yaitu dan APBD I BPTP, APBD II Pemda DKP,APBD DKP. Berdasarkan hasil analisis di atas dapat di simpulkan bahwa dana bantuan dari pemerintah tersebut sudah cukup memadai untuk mendukung program KRPL berjalan optimal.

\section{Karateristik dan Kemampuan Agen Pelaksana}

Untuk faktor karakteristik di lihat dari keseriusan para implementor dilapangan dalam melakukan serangkaian penguatan sistem hingga pembuatan peraturan pendukung (Standard Oparetional Procedur) untuk melaksankan agar program berjalan dengan baik. Disini peneliti melihat keseriusan akan terlaksannya program KRPL dengan baik dari ada tidaknya peraturan desa cinta mekar yang di buat semenjak program ini diluncurkan. Berikut hasil kutipan hasil wawancara peneliti dengan informan sekretaris desa cinta mekar terkait ada tidaknya peraturan atau SOP. yang dibuat untuk mendukung program KRPL di desa cinta mekar Kecamatan Serangpanjang: "kalau SOP untuk KRPL kami belum ada ya.. tapi SOP untuk didesa sendiri kami sudah membuatnya.. “. Berikut kutipan wawancara dengan informan Penyuluh Pendamping desa cinta mekar: "Nah untuk SOP nya kalo saya kurang tau ya.. karena saya kan hanya sebagai pendamping KWT saja.. kalo untuk SOP ada mungkin di desa". Berikut hasil kutipan wawancara informan ketua KWT desa cinta mekar : "kalau SOP KRPL kita tidak pegang...sepertinya memang tidak ada ya.. pihak desa juga pasti memberikan kalo memang ada.."

Berdasarkan hasil analisis kutipan wawancara di atas menurut 3 informan menyatakan bahwa tidak adanya mengenai peraturan pendukung (Standard Operational Procedure) atau SOP untuk implementasi program KRPL. dalam hal ini pemerintah setempat (Pihak Desa) terlihat kurang memperhatikan mengenai SOP KRPL dimana adanya SOP ini dapat menjadi acuan serta petunjuk bagi pengelola dan penyuluh pendamping KRPL dalam implementasi program KRPL agar bisa berjalan optimal dengan mengikuti prosedur yang ada. Jika memperhatikan teori dari G Shabbir Cheema dan Dennis A. Rondinelli karakteristik mencakup struktur birokrasi,normanorma dan pola-pola hubungan yang terjadi dalam birokrasi yang semuanya itu akan mempengaruhi implementasi suatu program.

Berdasarkan hasil analisis diatas dapat di simpulkan bahwa peran karakteristik sangat mempengaruhi para partisipan untuk mendukung atau menolak. Berdasarkan kutipan hasil wawancara dengan informan terlihat jelas bahwa pemerintah setempat kurang mendukung dalam pelaksanaan program KRPL di Desa Cinta Mekar. Selanjutnya,kemampuan agen pelaksana yang dimiliki desa cinta mekar merupakan salah satu indikator dari karakteristik pelaksana untuk pengelola dan pendamping desa cinta mekar sendiri berdasarkan pengamatan serta wawancara yang peneliti lakukan membutikan bahwa pengelola dan pemilihan pendamping dikuasai oleh orang-orang 
yang profesional dalam bidangnya seperti ketua KWT mekar wangi sudah menjabat sebagai ketua kelompok wanita tani di tahun 2019. Untuk pemilihan pendamping desa juga mempunyai kemampuan sesuai bidangnya dipilih dari badan pertanian kecamatan serangpanjang, pendamping desa dipilih langsung oleh dinas ketahanan pangan jadi untuk pelaksanaan Program KRPL di kelola oleh orang-orang yang tepat yang memiliki kemampuan untuk mengelola KRPL dengan baik.

Berdasarkan hasil analisis dengan informan di atas dapat dikatakan bahwa untuk karakteristik dan kemampuan agen pelaksana sangat mempengaruhi untuk mendukung proses implementasi program agar program bisa berjalan dengan baik sesuai yang di harapkan. Jika memperhatikan teori dari G Shabbir Cheema dan Dennis A. Rondinelli karakteristik dan kemampuan agen pelaksana mencakup struktur birokrasi,norma-norma dan pola-pola hubungan yang terjadi dalam birokrasi yang semuanya itu akan mempengaruhi implementasi suatu program. Berdasarkan hasil analisis diatas dapat disimpulkan bahwa peran pelaksana dalam menduung implementasi program sangat mempengaruhi agar program berjalan dengan baik.

\section{Kesimpulan}

Berdasarakan hasil analisis dalam pelaksanaan Program KRPL di Desa Cinta Mekar (Kelompok Wanita Tani Mekar Wangi) Kecamatan Serangpanjang dapat disimpulkan bahwa Implementasi Program Kawasan Rumah Pangan Lestari di Desa Cinta Mekar Kecamatan Serangpanjang belum maksimal dalam pelaksanaannya,terutama dalam hal karakteristik dan kemampuan agen pelaksana dan kondisi lingkungan yang belum maksimal serta provider (Desa) yang belum mendukung.

Kondisi Lingkungan belum mendukung program KRPL berjalan dengan optimal terlihat dari faktor cuaca serta serangan hama dan lokasi atau media tanam yang masih terbatas. Karakeristik dan Kemampuan Agen Pelaksana masih belum sesuai dengan harapan masyarakat terlihat dari pengelola KRPL KWT mekar wangi kurang menguasai tehknik budidaya tanaman dan kurang aktifnya KWT mekar wangi dalam budidaya tanaman. Hubungan Antar Organinasi masih belum sesuai dengan harapan KWT (Kelompok Wanita Tani) telihat dari pemerintah setempat kurang mendukung KWT dalam pelaksanaan program KRPL berjalan optimal. berdasarkan hasil penelitian dan jika dikaitkan dengan teori G Shabbir Cheema dan Dennis A. Rondinelli. Maka inti penting hasil kajian meliputi : kondisi lingkungan belum cukup mendukung proses implementasi berjalan dengan baik; hubungan antar organisasi masih kurang mendukung terlihat pemerintah setempat kurang memperhatikan kinerja KWT, sumber daya untuk implementasi program yang dimiliki sudah cukup memadai baik dari sumber daya maupun sumber daya finansial, dan karakteristik dan kemapuan agen pelaksana masih belum sesuai dengan harapan masyarakat. 


\section{Referensi}

Agustino, Leo.2008. Dasar-dasar Kebijakan Publik. Alfabeta:Bandung.

Alfatih, Andy.2010.Implementasi Kebijakan dan Pembedayaan Masyarakat. Bandun: Unpad Press.

Creswell, John W.2010. Research Design Pendekatan Kuantitatif,Kualitatif dan mixed Edisi Ketiga. Yogyakarta: Pustaka Pelajar

Dunn. William N. 1981. Analisis Kebijakan Publik Formulasi Implementasi dan Evaluasi Jakarta: PT. Gramedia Pustaka

Dye, Thomas R.1981. Understanding Public Policy. 3th Englewood Cliffs,NJ:Prentice Hall.

Hanifah Harsono,2002,Implementai Kebijakan dan Politik, Jakarta, Rineka Cipta

Hessel,Nogi,Tangkilisan,2003, Kebijakan publik Yang Membumi,Lukman Offset,Yogyakarta.

Islamy,M.Irfan,2001, Prinsip-Prinsip Perumusan Kebijakan Negara, Bumi Aksara,Jakarta

Jones, Charles O.1996.Pengantar Kebijakan Publik (Publik Policy) Terjemahan Rick Ismanto, Jakarta: Penerbit PT Raja Grafindo Persada.

Nugroho,Riant,2003. Kebijakan Publik Formulasi,Implementasi dan Evaluasi Jakararta. PT Gramedia.

Pedoman Umum Kawasan Rumah Pangan Lestari (KRPL) Tahun 2015

Pedoman Pelaksanaan Program P2KP Tahun 2013

Peraturan Presiden Nomor 22 Tahun 2009 Tentang Kebijakan Percepatan Penganekaragaman Konsumsi Pangan BerBasis Sumber Daya Lokal.

Peraturan Menteri Pertanian Nomor 23 Tahun 2009 Tentang Gerakan P2KP Berbasis Sumber Daya Lokal.

Peraturan Menteri Pertanian Nomor: 15 Permentan OT.140/2/2013 Tentang Peningkatan Diservikasi dan Keahanan Pangan.

Petunjuk Teknis KRPL Tahun 2018

Subarsono, AG.2011. Analisis Kebijkan Publik, Yogyakarta: Pustaka Pelajar.

Sugiyono,2008. Metode Penelitian Kualitatif (R\&D), Bandung: Alfabeta.

Santoso, Purwo,2004 dkk (ed). Menembus Ortodoksi Kajian Kebijakan Publik. Fisipol UGM.

Suwitri,Sri. 2008. Konsep Dasar Kebijkan Publik. Badan Penerbit Unversitas Diponegoro, Semaranng.

Suradinata, Ermaya. 1993. Kebijakan, Keputusan dan Kebijaksanaan. Bandung:Mandar Maju.

Tachjan, 2006. Implementasi Kebijakan Publik. AIPI Bandung PUSLIT KP2W LEMLIT UNPAD.

Tilaar, H.A.R dan Riant Nugroho. 2008. Kebijakan Pendidikan. Yogyakarta: Pustaka Pelajar. 


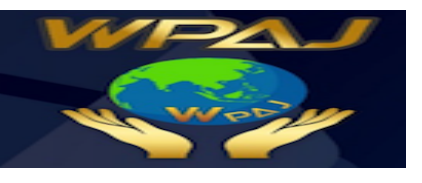

Volume 1 Issue 1, Juni 2019

https://ejournal.unsub.ac.id/index.php/publik

Wibowo, Suraba, S,1994. Evaluasi Kebijakan Publik. Jakarta: PT. Raja Grafindo Persadaya.

Widodo, Joko. 2001. Good Governance: Telaah Dari Dimensi: Akuntabilitas dan Kontrol Birokrasi pada Era Desentralisasi dan Otonomi Daerah.

Wahab,Abdul Soclihin. 2008. Analisis Kebijaksanaan dari Formulasi ke Implementasi Kebijaksanaan Negara, Jakarta: Bumi Aksara.

Winarno, Budi. 2002. Kebijakan dan Proses kebijakan Publik. Yogyakarta: MediaPresiondo.

Winarno, Budi. 2007. Kebijakan Publik: Teori dan Proses. Yogyakarta: Media Presindo 